\title{
Methods of Soybean Genotypes Selection in Paraná State, Brazil
}

\author{
Lorena M. Lara ${ }^{1}$, Michel Esper Neto ${ }^{1}$, Hugo Zeni Neto ${ }^{1}$, Alessandro L. Braccini ${ }^{1}$, Fernanda B. G. Anghinoni ${ }^{1}$, \\ Rayssa F. Santos ${ }^{1}$, Luiz H. S. Lima ${ }^{1} \&$ Alexandre Garcia ${ }^{2}$ \\ ${ }^{1}$ Agronomy Department, Maringá State University, Maringá, PR, Brazil \\ ${ }^{2}$ Company Tropical Melhoramento Genético, Londrina, PR, Brazil \\ Correspondence: Lorena M. Lara, Agronomy Department, Maringá State University, Colombo Avenue, n. \\ 5790-Bloco J45, 87020-900, Maringá, Paraná State, Brazil. Tel: 55-443-011-1375. E-mail: \\ lmoreiralara@gmail.com
}

Received: October 6, 2018

Accepted: November 9, 2018 Online Published: January 15, 2019

doi:10.5539/jas.v11n2p100

URL: https://doi.org/10.5539/jas.v11n2p100

\begin{abstract}
The soybean crop presents several cultivars available. The performance of each cultivar in the field is associated with its genetic characteristics and the interaction of these with environment. Specific recommendations according to environment are made soybean cultivars release based on adaptability and stability analyzes. This research evaluated twelve soybean cultivars in the northern region of Paraná State Brazil, in order to recommend the most suitable and stable cultivar. The experiment was designed in complete randomized blocks four sites: Maringá, Floresta, Cambé and Apucarana, with four replications, in 2017/2018 growing season. Totaling 48 experimental units per site, that is, a total of 192 in the experiment. The variables evaluated were: one thousand grain mass, productivity, hectoliter weight, number of pods per plant and number of grains per plant. The cultivars were evaluated for adaptability and stability by the methodologies proposed by Lin and Binns (1988) and a bi-segmented regression method according to Cruz et al. (1989). The results indicated that the selection was more reliable when the two methodologies were used, due to their correlation coefficients. Soybean cultivar 3 presented promising behavior in regions studied.
\end{abstract}

Keywords: adaptability, stability, selection index, interaction

\section{Introduction}

During 2017/18 growing season, Paraná State was the third largest in area cultivated with soybean [Glycine max (L). Merr.]. in Brazil (5.4 million ha) preceded by Mato Grosso State (9.6 million ha) and Rio Grande do Sul State (5.6 million ha). Although in terms of soybean yield, Paraná State is leader with average of $3.5 \mathrm{Mg} \mathrm{ha}^{-1}$ in 2017/18 growing season, the total amount of soybean produced in Paraná State in the previous growing season was around 19.2 million tons (CONAB, 2018). The counties of Apucarana, Cambé, Floresta and Maringá (located in Paraná State) produced approximately 300 thousand Mg of soybean grains, representing about 15\% of grains produced in the north central of Paraná State.

Soybean crop has wide variety of cultivars (Carvalho et al., 2010). There are several soybean maturation groups available to attend photoperiod variations throughout the different latitudes. The choice of maturation group and soybean habit growth characterize the development cycle and phases of each growing stage to plan all crop management practices from sowing until harvest (Zanon et al., 2015). Brazilian farmers need early and late maturing cultivars to sow maize after the soybean harvest (Carvalho et al., 2010).

A lot of phenotypic characteristics including yield that have economic impact depends mainly on genotype (G), environment $(\mathrm{E})$ and their interactions $(\mathrm{G} \times \mathrm{E})$. These interactions demonstrate that genotype expression depend on environmental conditions. The same genotype may exhibit different behavior during different years and growing locations due to innumerable adverse effects from the environment. Therefore, it is necessary to include adapted and stable genotypes in soybean breeding programs (Prado et al., 2001).

Adaptability and stability analysis allow statistical identification of these genotypes. According to Cruz et al. (2012), adaptability is the genotype's ability to take advantages of stimuli provided by the environment. On the other hand, stability is the ability to predict behavior according to the environmental stimulus exposed. Soybean breeders seek to select cultivars which demonstrate broad adaptability, high stability and genotypes recommended for specific environment (Barros et al., 2010). 
There are several methodologies to accomplish the analysis procedures to select superior genotypes, that differ in concepts, parameters used and biometric procedures that aim to measure these $\mathrm{G} \times \mathrm{E}$ interactions (Rocha, 2002). The models based on the bi-segmented regression method contemplate the group's formation of favorable and unfavorable environments, with the presence of positive and negative indices respectively (Cruz et al., 1989). Otherwise, the methodology developed by Lin and Binns (1988) is based on the mean square of distance between the average maximum response obtained in the environment and the general average response of the cultivar, being defined as the difference between the average of the cultivars in each environment and the general average.

The research hypothesis is based on the existence of more adapted and stable soybean cultivars for southern climate of Brazil and on the efficiency in selection of adapted and stable cultivars by combination of two different methodologies. The aim was to evaluate the adaptability and stability of the 12 most cultivated genotypes in this region, with a purpose to recommend the genotype with major yield potential for prevailing environmental conditions.

\section{Material and Methods}

\subsection{Environments and Experimental Design}

The experiments were carried out during 2017/18 growing season, in four sites: 1) Technology Dissemination Unit (TDU) of Cooperativa Agroindustrial de Maringá (COCAMAR) in Floresta, Paraná State, located at a latitude $23^{\circ} 35^{\prime} 42^{\prime \prime}$ south and longitude $52^{\circ} 04^{\prime} 02^{\prime \prime}$ west, and altitude of $395 \mathrm{~m}$ above mean sea level; 2) Iguatemi Experimental Farm of Maringá State University (UEM), in Maringá, Paraná State, located at a latitude of $23^{\circ} 02^{\prime} 22^{\prime \prime}$ south and longitude of $52^{\circ} 04^{\prime} 32^{\prime \prime}$ west, and altitude of $509 \mathrm{~m}$ above mean sea level; 3) Soybean Research Center, located on Cambé, Paraná State, located at a latitude of $23^{\circ} 15^{\prime} 02^{\prime \prime}$ south and longitude of $51^{\circ} 14^{\prime} 56^{\prime \prime}$ to the west, and altitude of $650 \mathrm{~m}$ above mean sea level and 4) Cortês Farm, located in Apucarana, Paraná State, located at a latitude of $23^{\circ} 33^{\prime} 47^{\prime \prime}$ south and longitude of $51^{\circ} 22^{\prime} 41^{\prime \prime}$ west, and altitude of $764 \mathrm{~m}$ above mean sea level.

Twelve commercial soybean cultivars, named from 1 to 12 , with a maturation group ranging from 4.8 to 6.7 were sown (Table 1). In the region under analysis in Paraná State, maturation group indicated ranges from 5.5 to 8. All soybean cultivars had indeterminate growth habit, except cultivar 4 which had semi-determinate growth habit (Sediyama et al., 2015).

Every $13.5 \mathrm{~m}^{2}$ plot consisted of 6 rows, $5 \mathrm{~m}$ long, spaced $0.45 \mathrm{~m}$ apart with useful area of $5.4 \mathrm{~m}^{2}$. The experiment was outlined in completely randomized blocks with four replications with a total of 48 experimental units. All cultivars were sown at a density of 31 seeds $\mathrm{m}^{-2}$. All cultural treatments from sowing to harvest were carried out following the guidelines for technologies, products and services (TPS) of Embrapa (2013).

Table 1. Cultivars and their characteristics with commercial nomenclature decoding

\begin{tabular}{lllllllllllll}
\hline Cultivars & 1 & 2 & 3 & 4 & 5 & 6 & 7 & 8 & 9 & 10 & 11 & 12 \\
\hline Maturation Group & 6.4 & 4.8 & 6.1 & 6.2 & 6.3 & 5.9 & 6.4 & 6.1 & 6.3 & 5.9 & 6.7 & 6.3 \\
Growth habit & I & I & I & SD & I & I & I & I & I & I & I & I \\
\hline
\end{tabular}

Note. I: Indeterminate; SD: Semi-determinate.

\subsection{Evaluated Variables}

Five variables namely yield (YIE), thousand grain mass (TGM), Hectoliter mass (HEM), pods per plant (NP) and number of grains per plant (NG) were evaluated. TGM was determined by weighed 8 subsamples of 100 grains on analytical precision balance of one milligram precision. Then, results were multiplied by 10 , according to MAPA (2009). HEM corresponds to mass of 100 liters of soybean grain expressed in $\mathrm{kg} \mathrm{hl}^{-1}$. This variable was obtained by means of Portable Grain Moisture Meter, brand AGROLOGIC, Model AL-101.

At growing stage R6, five plants per plot were collected (Sediyama et al., 2015), and by direct counting were obtained NP and NG. The YIE per $5.4 \mathrm{~m}^{2}$ area was determined, the one external rows and $1.0 \mathrm{~m}$ at either end of the central rows were disregarded; YIE was expressed in $\mathrm{kg} \mathrm{ha}^{-1}$ and seed moisture correction to $13 \%$ wet basis.

\subsection{Data Analysis}

All data were submitted to basic assumptions of statistical analysis by Lilliefors (Lilliefor, 1967) and Bartelett (Steel et al., 1997) tests $(p<0.05)$. Then the data were submitted to $\mathrm{F}$ test (qualitative treatments) and the results 
obtained at four sites were analyzed in separate and compared by means of joint analysis (Zimmermann, 2014). Adaptability and stability of the materials were analyzed using Lin and Binns (1988) methodologies and bi-segmented regression according to Cruz et al. (1989).

According to Lin and Binns (1988), the overall superiority of one cultivar is defined by the square mean between the response of cultivar and the maximum response in all the environments, thus, the ideal genotype is the one with the lowest stability index $(\mathrm{P}) . \mathrm{P}$ is a parameter that quantifies the deviation of a cultivar from the highest performance material in each environment, obtained by the estimation of $\mathrm{Pi}$, where $\mathrm{i}$ is the number of evaluated genotypes. It acts by estimate a relative measure of a hypothetical cultivar that presents general adaptability and regression coefficient equal to, or close to, one unit.

In the method of the bi-segmented linear regression proposed by Cruz et al. (1989), are given by adaptability and stability parameters, being the mean $\left(\beta_{0 \mathrm{i}}\right)$ and the linear response to unfavorable $\left(\beta_{1 \mathrm{i}}\right)$ and favorable $\left(\beta_{1 \mathrm{i}}+\beta_{2 \mathrm{i}}\right)$ environments. In this methodology, stability is observed through the deviation of the regression of each genotype as a function of the environmental variations $\left(\sigma_{\delta i}^{2}\right)$ (Garbuglio et al., 2007).

To evaluate variables, among each other, the data were submitted to Pearson's linear correlation analysis $(p<$ 0.05 ), and the classification was made based on the classic selection index. All statistical analyzes were performed using the Genes Software (Cruz, 2016).

\section{Results and Discussion}

\subsection{Variance Analysis}

Soybean yield did not present significant differences among cultivars (Table 2). This can be explained by the similarity of genetic basis content in cultivars tested (Miranda et al., 2007). This similarity may be associated with equal contribution of genes to productive cultivars. Because of this, the twelve commercial cultivars used may contain similar genetic bases (Kiihl, 1994). Cultivar 2 belongs to maturation group 4.8, had its harvest advanced in thirty days in all the sites comparing with the other cultivars, that were harvested on the same day. The soybean cultivar choice depends on a lot of factors and among them is the land use planning after soybean crop. Normally Brazilian farmers grow maize as a second crop, therefore earlier soybean cultivars should be chosen to avoid unfavorable weather for maize cultivation later, mainly due to frost and lack of rainfall.

Maize development under favorable climatic conditions increases possibilities to reach higher yield potential. The influence of sowing time on maize grain yield in second crop is directly related to rainfall regime. Better distribution of rainfall is overriding, mainly in the final stages of vegetative development and at the beginning of reproductive development (Simão et al., 2018). Cardoso et al. (2004) evaluated 12 maize sowing times from January to April, with and without water limitation. The authors have observed $38 \%$ decrease in yield due to delayed sowing time and $44 \%$ decrease due to limitation in crop's water supply. Because of this reason, soybean with lower maturation group may be useful when farmers want to grow maize as second crop to realize higher yields by sowing early time.

Cordeiro Júnior et al. (2017) evaluated 30 commercial soybean cultivars in 2016/17 growing season, with cultivar maturation groups ranging from 5.8 to 8.2 and genotypes of determinate, indeterminate and semi-determinate growth habits. They observed similar results for yield. Soybean maturation group (5.8) did not differ statistically from cultivars with larger maturation groups, such as 7.3 and 8.2. In addition, they also observed that growth habit was not determinate for this variable.

Regarding environments there were significant differences for yield and TGM (Table 2). For yield, all cultivars had a particular performance in each environment;

TGM was significant among cultivars. Perini et al. (2012) evaluated seven soybean cultivars and also observed different mass of grain among cultivars. In addition, they have observed inverse relation between, grain mass and number of grains per plant, that means a higher TGM results in lowest number of grains per plant and vice versa.

NG were not significant when analyzing the factors, treatments (genotypes) and environments, separately. There were interactions between genotypes $\mathrm{x}$ environments, in other words the tested genotypes responded differently in environments for this variable. Unfolding the ANOVA for factors Maringá and Apucarana, environments presented differences among treatments (Table 2), Cambé and Floresta, did not. HEM and number of pods per plant were not significant either. 
Table 2. Variance analysis for treatments within environments for the variable's yield, number of grains per plant (NG) and thousand grain mass (TGM)

\begin{tabular}{|c|c|c|c|c|c|c|c|}
\hline \multirow{2}{*}{ VS } & \multirow{2}{*}{ Treat } & \multicolumn{2}{|c|}{ Yield } & \multicolumn{2}{|c|}{ NG } & \multicolumn{2}{|c|}{ TGM } \\
\hline & & $\mathrm{F}$ & Prob. & $\mathrm{F}$ & Prob. & $\mathrm{F}$ & Prob. \\
\hline AMB/TRAT & 1 & 10.06 & 0.00000 & 1.08 & 0.36 & 1.29 & 0.28 \\
\hline AMB/TRAT & 2 & 8.40 & 0.00003 & 1.54 & 0.21 & 4.08 & 0.01 \\
\hline AMB/TRAT & 3 & 8.01 & 0.00005 & 0.88 & 1.00 & 1.26 & 0.29 \\
\hline AMB/TRAT & 4 & 9.45 & 0.00000 & 1.26 & 0.29 & 0.63 & 1.00 \\
\hline AMB/TRAT & 5 & 9.47 & 0.00000 & 0.66 & 1.00 & 2.79 & 0.05 \\
\hline AMB/TRAT & 6 & 9.59 & 0.00000 & 0.07 & 1.00 & 1.28 & 0.29 \\
\hline AMB/TRAT & 7 & 9.60 & 0.00000 & 0.72 & 1.00 & 0.76 & 1.00 \\
\hline AMB/TRAT & 8 & 9.59 & 0.00000 & 0.80 & 1.00 & 3.66 & 0.02 \\
\hline AMB/TRAT & 9 & 10.33 & 0.00000 & 4.24 & 0.01 & 1.28 & 0.29 \\
\hline AMB/TRAT & 10 & 7.70 & 0.00008 & 1.56 & 0.20 & 0.62 & 1.00 \\
\hline AMB/TRAT & 11 & 7.20 & 0.00015 & 0.68 & 1.00 & 3.32 & 0.02 \\
\hline AMB/TRAT & 12 & 5.40 & 0.00151 & 4.09 & 0.01 & 1.32 & 0.27 \\
\hline
\end{tabular}

Note. $\mathrm{VS}=$ Variation source, Treat $=$ Treatment, Env $=$ Environment, Prob $=$ Probability, $\mathrm{F}=$ Value obtained by $\mathrm{F}$ test.

\subsection{Cultivar's Adaptability and Stability}

According to Lin and Binns (1988) methodology, cultivar 4 presented lower Pi for TGM (3.05) and yield $(59099,99)$ and was the second one for number of grains $(590,3053)$ preceded by cultivar $11(549,84)$ (Table 3$)$, thus it can be inferred that cultivar 4 presented greater stability, in other words, it exhibited predictable behavior when exposed to these environments. Otherwise, cultivar 7 had the highest Pi for TGM (1581.71) and cultivar 5 for yield (499727.73) and HEM (100.99) (Table 3).

Cultivar 2 had the highest values of $\mathrm{P} i$ for number of pods per plant $(942,7141)$ and number of seeds per plant $(10645,5456)$ (Table 3). Polizel et al. (2013) found greater stability for the UFU 23 genotype because its value of $\mathrm{P} i$ was the lowest and its percentage of contribution to the interaction was low $(1.11 \%)$, thus it was considered as a promising genotype. In contrast, the genotype Msoy 6101 was considered of low stability because it had the highest observed Pi value and percentage of contribution to the high interaction (17.19\%).

Table 3. General Pi of soybean genotypes, obtained by Lin and Binns (1988) methodology, in the north region of Paraná State in 2017/18 growing season

\begin{tabular}{llllll}
\hline Genotype & TGM & YIE. & HEM & NP & NG \\
\hline 1 & 1093.78 & 190545.98 & 1.64 & 377.49 & 2306.91 \\
2 & 1078.38 & 242842.31 & 40.65 & 942.71 & 10645.55 \\
3 & 541.87 & 163391.20 & 1.17 & 351.95 & 2027.28 \\
4 & 3.05 & 59099.99 & 1.07 & 42.48 & 590.31 \\
5 & 713.51 & 499727.73 & 100.99 & 346.11 & 2755.45 \\
6 & 908.78 & 90605.45 & 1.61 & 291.57 & 1935.82 \\
7 & 1581.75 & 63289.91 & 1.31 & 385.38 & 2334.65 \\
8 & 731.56 & 365984.86 & 55.79 & 364.47 & 2338.79 \\
9 & 430.05 & 193637.87 & 3.43 & 382.03 & 2432.45 \\
10 & 422.74 & 179244.58 & 1.69 & 253.23 & 2111.59 \\
11 & 1379.56 & 183351.34 & 49.03 & 91.43 & 549.84 \\
12 & 225.85 & 275157.47 & 1.81 & 295.12 & 3549.94 \\
\hline
\end{tabular}

Note. TGM $=$ Thousand grain mass; YIE $=$ Yield, HEM $=$ Hectoliter mass, $\mathrm{NP}=$ Number of pods per plant and $\mathrm{NG}=$ Number of grain per plant. 
Regarding bi-segmented regression methodology for environmental classification, Maringá and Floresta, were classified as unfavorable environments, although Apucarana and Cambé were classified as favorable for TGM and YIE (Table 4). This classification may have been influenced by altitude, since sites classified as favorable were those at higher altitude. Lower soybean yields were revealed by Teixidó (2013) when cultivated at low altitudes. This author identified a better performance in the soybean cultivars in higher altitude environment and consequently greater thermal amplitude.

For the variable number of grains per plant, a different classification was observed, only Apucarana was considered favorable (Table 4). This could have occurred due to favorable climate at highest altitude for this site $(764 \mathrm{~m})$. This methodology classifies the environments considering the set of environmental factors which influence the productivity of genotypes, being possible to highlight best environment based on the variable studied (Fernandes Júnior et al., 2013).

Table 4. Environmental classification as favorable (F) and unfavorable (U), following the Cruz et al. (1989) methodology in the 2017/18 growing season

\begin{tabular}{llll}
\hline Envirolment & Thousand grain mass & Yield & Number of grain per plant \\
\hline Maringá & $\mathrm{U}$ & $\mathrm{U}$ & $\mathrm{U}$ \\
Apucarana & $\mathrm{F}$ & $\mathrm{F}$ & $\mathrm{F}$ \\
Floresta & $\mathrm{U}$ & $\mathrm{U}$ & $\mathrm{U}$ \\
Cambé & $\mathrm{F}$ & $\mathrm{F}$ & $\mathrm{U}$ \\
\hline
\end{tabular}

In the bi-segmented linear regression method, adaptability and stability parameters were estimated for yield variable. Cultivar 10 is closest to ideal genotype, because it presents the fourth largest $\widehat{\beta}_{0} ; \widehat{\beta}_{1}<1$, that means, presents low responsiveness at unfavorable sites and $\widehat{\beta}_{1}+\widehat{\beta}_{2}>1$, indicating that the cultivar responds to favorable environments, besides being stable because $\hat{\sigma}_{\delta}^{2}$ is not significant (Table 5).

The highest values of $\widehat{\beta}_{0}$ were observed for cultivars 4 and 7 and the lo west values for cultivars 5 and 8 , which also did not present significant $\hat{\sigma}_{\delta}^{2}$ indicating that they were not stable for these growing conditions (Table 5). Garbuglio et al. (2007), evaluated 27 maize cultivars in 22 sites in the southern region of Brazil, and observed that for the two cultivars with lower value of $\widehat{\beta}_{0}$, stability was not found using the same methodology. Backes et al. (2005) evaluated 13 beans genotypes in Santa Catarina State, in 10 sites for two growing season, and found that the two lowest values of yield did not show stability by the bi-segmented methodology. These authors observed stability (non-significant $\hat{\sigma}_{\delta}^{2}$ ) for cultivars which reached higher yield averages $\left(\hat{\beta}_{0}\right)$.

The parameter which demonstrates cultivars behavior in unfavorable environments is the $\hat{\beta}_{1}$, and cultivar selection depends on the aim of the breeders. For cultivars with $\widehat{\beta}_{1}>1$, responses to environmental improvement are observed, but there is also cultivars sensibility when stress conditions happened. On the other hand, cultivars with $\widehat{\beta}_{1}<1$, are more rustic to environmental adversities, although yield responses are smaller (Cruz, 2012).

Cultivars 4 and 7 presented responsive behavior to environmental improvement $\left(\widehat{\beta}_{1}>1\right)$. Thus, investments in technology resources, such as water availability, nutrition and control of pests and diseases may allow higher yield patterns, although without favorable conditions these cultivars will have its yield impaired. Otherwise, cultivar 5 was shown to be less sensitive to environmental adversities as well as 3 and 10 (Table 5), and may be indicated for unfavorable environments $\left(\widehat{\beta}_{1}<1\right.$ and $\hat{\sigma}_{\delta}^{2}$ non-significant). These results corroborate with those obtained by Backes et al. (2005), whose tested the bi-segmented linear regression methodology and found cultivars that could be recommended for unfavorable environments, with $\hat{\beta}_{1}<1$ and $\hat{\sigma}_{\delta}^{2}$ non-significant.

The $\hat{\beta}_{1}+\hat{\beta}_{2}$ parameter is associated with cultivars behavior in favorable environments. None of cultivars showed broad adaptability with com $\widehat{\beta}_{1}+\widehat{\beta}_{2}=1$. Cultivars 5 and 8 presented $\widehat{\beta}_{1}+\widehat{\beta}_{2}>1$ (Table 8), indicating that they would be recommendable for specific favorable environments, if they had presented satisfactory yield. Differently, cultivars 4 and 7 had $\widehat{\beta}_{1}+\widehat{\beta}_{2}<1$, that means, they did not respond satisfactorily to favorable environments, but presented better yields averages $\left(\widehat{\beta}_{0}\right)$ (Table 8$)$. 
Table 5. Adaptability and stability parameters for yield estimated by the bi-segmented linear regression method proposed by Cruz et al. (1989), in north of Paraná State in 2017/18 growing season

\begin{tabular}{llllll}
\hline Genotype & $\beta_{0}$ & $\beta_{1}$ & $\beta_{2}$ & $\beta_{1}+\beta_{2}$ & $\mathrm{~F} \hat{\sigma}_{\delta}^{2}$ \\
\hline 1 & 3938.46 & 1.07 & 0.96 & 2.03 & $0.004^{\mathrm{ns}}$ \\
2 & 3862.06 & 1.02 & -1.82 & -0.80 & $0.07^{\text {ns }}$ \\
3 & 3983.24 & 0.96 & 0.67 & 1.63 & $0.17^{\text {ns }}$ \\
4 & 4257.21 & 1.09 & -1.53 & -0.45 & $0.32^{\text {ns }}$ \\
5 & 3751.81 & 0.88 & 2.47 & 3.35 & $1.72^{\text {n }}$ \\
6 & 4063.93 & 1.10 & -0.26 & 0.84 & $0.02^{\text {ns }}$ \\
7 & 4135.23 & 1.10 & -0.36 & 0.73 & $0.05^{\text {ns }}$ \\
8 & 3700.73 & 1.05 & 0.24 & 1.29 & $1.71^{*}$ \\
9 & 3952.60 & 1.12 & -0.95 & 0.16 & $1.68^{*}$ \\
10 & 4007.10 & 0.92 & 0.92 & 1.84 & $0.51^{\text {ns }}$ \\
11 & 3989.85 & 0.93 & -0.71 & 0.22 & $1.34^{*}$ \\
12 & 3922.10 & 0.77 & 0.39 & 1.15 & $1.38^{*}$ \\
\hline
\end{tabular}

Note. $\beta_{0 \mathrm{i}}=$ mean, $\beta_{1 \mathrm{i}}=$ response to unfavorable environments, $\beta_{2 \mathrm{i}}=$ component of the parameter related to favorable environments, $\beta_{1 \mathrm{i}}+\beta_{2 \mathrm{i}}=$ response to favorable environments, $\sigma_{\delta}^{2}=$ deviation of the regression of each genotype as a function of the environmental variations, *Significant at $5 \%$ probability and ${ }^{\text {ns }}$ non-significant, by F test.

\subsection{Classical Selection Index and Correlation}

Classical index shows the distribution of expected genetic gains in a more balanced way (Martins et al., 2003) and through this index the first one third of cultivars classified was selected (5, 3, 9 and 4). As an economic weight, the coefficient of genetic variation corresponding to each variable was used as suggested by Cruz (1990).

Cultivars 5, 3, 9 and 4 were the first in the classification of the index in the direction of the increases and cultivar 2 was the lower limit of the selection. Cultivars 4 and 3 were also classified in the first one third by the general parameter (Pi) (Table 3).

According to Cruz, et al. (1989) methodology (Table 5), cultivars 5 and 3 were classified as adapted to unfavorable environments $\left(\widehat{\beta}_{1}<1\right)$ and cultivars 5 and 9 presented no stability $\left(\hat{\sigma}_{\delta}^{2}\right.$ significant $)$. As for favorable environments, cultivars 5 and 3 could be recommended for favorable environments $\left(\widehat{\beta}_{1}+\widehat{\beta}_{2}>1\right)$. Cultivar 2 in both methodologies maintained patterns that are not selectable (Table 6). The coefficients of determination explained well the behavior of the cultivars discussed because of the index selection $(5,3,9,4$ and 2$)$ against the environmental variations.

Table 6. Adaptability and stability parameters estimated by the methods proposed by Cruz et al. (1989) and Lin and Binns (1988) for yield variable, in north region of Paraná State in the 2017/18 growing season

\begin{tabular}{lllll}
\hline Genotype & $\mathrm{Pi}(+)$ & $\mathrm{Pi}(-)$ & $\beta_{1}$ & $\beta_{1}+\beta_{2}$ \\
\hline 1 & 239511.60 & 141580.40 & 1.07 & 2.03 \\
2 & 305090.00 & 180594.60 & 1.02 & -0.80 \\
3 & 275447.90 & 51334.48 & 0.96 & 1.63 \\
4 & 96654.15 & 21545.84 & 1.09 & -0.45 \\
5 & 606044.70 & 393410.70 & 0.88 & 3.35 \\
6 & 101370.30 & 79840.59 & 1.10 & 0.84 \\
7 & 52864.09 & 73715.72 & 1.10 & 0.73 \\
8 & 517776.40 & 214193.30 & 1.05 & 1.29 \\
9 & 72335.66 & 314940.10 & 1.11 & 0.16 \\
10 & 333527.40 & 24961.72 & 0.92 & 1.84 \\
11 & 140920.90 & 225781.80 & 0.93 & 0.22 \\
12 & 545013.20 & 5301.74 & 0.77 & 1.15 \\
\hline
\end{tabular}

Note. $\mathrm{Pi}(+)$ and $\mathrm{Pi}(-)$ are parameters referring to the methodology proposed by Lin and Bins (1988), and $\beta_{1}$ and $\beta_{1}+\beta_{2}$ to the methodology proposed by Cruz et al. (1989). 
Cultivar 3 was promising in the two methodologies used and was selected by the classical index. This behavior is observed, because in Pearson's correlation analysis between the parameters of favorable and unfavorable environments for yield was significant $(0.60)$ (Table 7$)$. The correlation between $\widehat{\beta}_{1}$ and Pi for positive environments $(\mathrm{Pi}+)$ was also significant, but inversely. In this case, the result was already expected because $\widehat{\beta}_{1}$ infers on unfavorable environments and $\mathrm{Pi}+$ on favorable environments, so the correspondence between the two parameters is -0.71 (Table 7).

These results do not corroborate with those observed by Pereira et al. (2009), who evaluated 71 sites with 16 genotypes and tested six methods of evaluation of the adaptability and stability analysis, in order to verify the presence of correspondence in the methodologies and did not found significant correlations between Cruz et al. (1989) and Lin and Binns (1988).

Polizel et al. (2013) evaluated seven methodologies of adaptability and stability analysis, among them Cruz et al. (1989) and Lin and Binns (1988) methodologies. They classified all genotypes in each methodology and made the simple Pearson correlations between the methodologies. They were able to observe that the methodology proposed by Lin and Binns (1988) and bi-segmented regression proposed by Cruz et al. (1989) are complementary and the use of both is recommended for the evaluation and recommendation of cultivars.

Table 7. Pearson correlation coefficients-estimates for adaptability and stability parameters obtained by 12 genotypes in four soybean sites, in the north of Paraná State in 2017/18 growing season

\begin{tabular}{lllll}
\hline & Pi $(+)$ & Pi $(-)$ & $\beta_{1}$ & $\beta_{1}+\beta_{2}$ \\
\hline $\operatorname{Pi}(+)$ & 1 & 0.22 & $-0.71^{*}$ & $0.60^{*}$ \\
$\operatorname{Pi}(-)$ & - & 1 & 0.07 & 0.23 \\
$\beta 1$ & - & - & 1 & -0.41 \\
$\beta 1+\beta 2$ & - & - & - & 1 \\
\hline
\end{tabular}

Note. $\mathrm{Pi}(+)$ and $\mathrm{Pi}(-)$ are parameters referring to the methodology proposed by Lin and Bins (1988), and $\beta_{1}$ and $\beta_{1}+\beta_{2}$ to the methodology proposed by Cruz et al. (1989). * Significant at 5\% probability, by t Student test.

\section{Conclusions}

The use of the methodology proposed by Lin and Binns (1988) and the one proposed by Cruz et al. (1989), when used together, can make the selection of cultivars more reliable, since in the case of this work they presented a good correlation, which concretely reveals the best place for possible recommendation.

The evaluated variables have different behavior in the different environments. There is no homogeneity when evaluated in heterogeneous climatic conditions.

Cultivar 3 presented promising behavior for the evaluated environments.

\section{Acknowledgements}

The study was supported financially by Coordenação de Aperfeiçoamento de Pessoal de Nível Superior (CAPES) and Conselho Nacional de Desenvolvimento Científico e Tecnológico (CNPq-PROC 141140/2017-8). The authors are indebted to COCAMAR (Cooperativa Agroindustrial de Maringá), TMG (Tropical Melhoramento Genético) and seed's laboratory from UEM (Universidade Estadual de Maringá).

\section{References}

Backes, R. L., Tavares Elias, H., Hemp, S., \& Nicknich, W. (2005). Adaptabilidade e estabilidade de genótipos de feijoeiro no Estado de Santa Catarina. Acta Scientiarum. Biological Sciences, 27(2), 309-314.

Barros, H. B., Sediyama, T., Texeira, R. C., Fidelis, R. R., Cruz, C. D., \& Reis, M. S. (2010). Adaptabilidade e estabilidade de genótipos de soja avaliados no estado do Mato Grosso. Revista Ceres, 57(3), $359-366$. https://doi.org/10.1590/S0034-737X2010000300011

Cardoso, C. O., Faria, R. T., \& Folegatti, M. V. (2004). Simulação do rendimento e riscos climáticos para o milho safrinha em Londrina-PR, utilizando o modelo ceres-maize. Engenharia Agrícola, 24, $291-300$. https://doi.org/10.1590/S0100-69162004000200007

Carvalho, E. R., Rezende, P. D., Ogoshi, F. G. A., Botrel, E. P., Alcantara, H. D., \& Santos, J. P. (2010). Desempenho de cultivares de soja [Glycine max (L.) Merrill] em cultivo de verão no sul de Minas Gerais. Ciência e Agrotecnologia, 34(4), 892-899. https://doi.org/10.1590/S0100-204X2005000500008 
CONAB (Companhia Nacional de Abastecimento). (2018). Boletim de acompanhamento da safra brasileira de grãos (Safra 2017/18-Sétimo Levantamento, Abril 2018).

Cordeiro Júnior, P. S., Finoto, E. L., Bárbaro-Torneli, I. M., Martins, M. H., Soares, M. B., Bolonhezi, D., \& Martins, A. L. M. (2017). Desempenho agronômico de cultivares de soja para a região centro norte paulista, safra 2016/17. Nucleus, 59-66. https://doi.org/10.3738/1982.2278.2820

Cruz, C. D. (1990). Aplicação de algumas técnicas multivariadas no melhoramento de plantas (Doctoral Dissertation), Escola Superior de Agricultura Luiz de Queiroz, Piracicaba, SP, Brazil).

Cruz, C. D. (2016). Genes Software-extended and integrated with the R, Matlab and Selegen. Acta Scientiarum. Agronomy, 38(4), 547-552. https://doi.org//10.4025/actasciagron.v38i4.32629

Cruz, C. D., Regazzi, A. J., \& Carneiro, P. C. S. (2012). Modelos biométricos aplicados ao melhoramento genético (1st ed.) Viçosa, MG: UFV.

Cruz, C. D., Torres, R. D., \& Vencovsky, R. (1989). An alternative approach to the stability analysis proposed by Silva and Barreto. Revista Brasileira de Genética, 12(3), 567-580.

Embrapa (Empresa Brasileira de Pesquisa Agropecuária). (2013). Tecnologias de produção de soja-Região central do Brasil 2012 e 2013. Londrina: Embrapa.

Fernandes Júnior, A. R., Andrade, J. A. D. C., Santos, P. C. D., Hoffmann, H. P., Chapola, R. G., Carneiro, M. S., \& Cursi, D. E. (2013). Adaptabilidade e estabilidade de clones de cana-de-açúcar. Bragantia, 72(2), 208-216. https://doi.org/10.1590/brag.2013.033

Garbuglio, D. D., Gerage, A. C., de Araújo, P. M., Junior, N. D. S. F., \& Shioga, P. S. (2007). Análise de fatores e regressão bissegmentada em estudos de estratificação ambiental e adaptabilidade em milho. Pesquisa Agropecuária Brasileira, 42(2), 183-191. https://doi.org/10.1590/S0100-204X2007000200006

Kiihl, R. A. S. (1994). Choice of cultivars. In E. Kueneman (Ed.), Tropical Soybean: Improvement and production (pp. 111-113). FAO-Plant Production and Protection Series (No. 27). Rome, Italy.

Lilliefors, H. W. (1967). On the Kolmogorov-Smirnov test for normality with mean and variance unknown. Journal of the American Statistical Association, 62(318), 399-402. https://doi.org/10.2307/2283970

Lin, C. S., \& Binns, M. R. (1988). A method of analyzing cultivar $\times$ location $\times$ year experiments: A new stability parameter. Theoretical and Applied Genetics, 76(3), 425-430.https://doi.org/10.1007/BF00265344

MAPA (Ministério da Agricultura, Pecuária e Abastecimento). (2009). Regras para análise de sementes. Brasília, DF: Secretaria de Defesa Agropecuária.

Martins, I. S., Cruz, C. D., Regazzi, A. J., \& Pires, I. E. (2003). Eficiência da seleção univariada direta e indireta e de índices de seleção em Eucalyptus grandis. Revista Árvore, 27(3), 327-333. https://doi.org/10.1590/ S0100-67622003000300008

Miranda, Z. D. F. S., Arias, C. A. A., Prete, C. E. C., Kiihl, R. A. D. S., Almeida, L. A. D., Toledo, J. F. F. D., \& Destro, D. (2007). Genetic characterization of ninety elite soybean cultivars using coefficient of parentage. Pesquisa Agropecuária Brasileira, 42(3), 363-369. https://doi.org/10.1590/S0100-204X2007000300009

Pereira, H. S., Melo, L. C., Del Peloso, M. J., Faria, L. D., Costa, J. D., Díaz, J. L. C., \& Wendland, A. (2009). Comparação de métodos de análise de adaptabilidade e estabilidade fenotípica em feijoeiro-comum. Pesquisa Agropecuária Brasileira, 44(4), 374-383. https://doi.org/10.1590/S0100204X2009000400007

Perini, L. J., Fonseca Júnior, N. S., Destro, D., \& Prete, C. E. C. (2012). Componentes da produção em cultivares de soja com crescimento determinado e indeterminado. Semina: Ciências Agrárias, 33(1), 2531-2544. https://doi.org/10.5433/1679-0359.2012v33Supl1p2531

Polizel, A. C., Juliatti, F. C., Hamawaki, O. T., Hamawaki, R. L., \& Guimarães, S. L. (2013). Adaptabilidade e estabilidade fenotípica de genótipos de soja no estado do Mato Grosso. Bioscience Journal, 29(4), 910-920.

Prado, E. E., Hiromoto, D. M., Godinho, V. D. P. C., Utumi, M. M., \& Ramalho, A. R. (2001). Adaptabilidade e estabilidade de cultivares de soja em cinco épocas de plantio no cerrado de Rondônia. Pesquisa Agropecuária Brasileira, 36(4), 625-635. https://doi.org/10.1590/S0100-204X2001000400005

Rocha, M. M. (2002). Seleção de linhagens experimentais de soja para adaptabilidade e estabilidade fenotípica (Doctoral dissertation, Escola Superior de Agricultura Luiz Queiroz, Universidade de São Paulo).

Sediyama, T., Silva, F., \& Borém, A. (2015). Soja: Do plantio à colheita. Universidade Federal de Viçosa, MG. 
Simão, E. D. P., de Resende, A. V., Gontijo Neto, M. M., Borghi, E., \& Vanin, A. (2018). Resposta do milho safrinha à adubação em duas épocas de semeadura. Revista Brasileira de Milho e Sorgo, 17(1), 76-90. https://doi.org/10.18512/1980-6477/rbms.v17n1p76-90

Steel, R. G. D., Torrie, J. H., \& Dickey, D. A. (1997). Principles and procedures of statistics: A biometrical approach. New York: McGraw Hill.

Teixidó, B. J. N. (2013). Rendimento de cultivares de milho e soja em diferentes zonas agroclimáticas do Paraguai (Doutoral dissertation, Curso de Agronomia, Universidade Federal de Pelotas, Pelotas).

Zanon, A. J., Minussi Winck, J. E., Streck, N. A., Rocha, T. S. M., Ceolin Cera, J., Richter, G. L., \& Marchesan, E. (2015). Desenvolvimento de cultivares de soja em função do grupo de maturação e tipo de crescimento em terras altas e terras baixas. Bragantia, 74(4), 400-411. https://doi.org/10.1590/1678-4499.0043

Zimmermann, F. J. P. (2014). Estatística aplicada à pesquisa agrícola (2nd ed.). Brasília, DF: Embrapa.

\section{Copyrights}

Copyright for this article is retained by the author(s), with first publication rights granted to the journal.

This is an open-access article distributed under the terms and conditions of the Creative Commons Attribution license (http://creativecommons.org/licenses/by/4.0/). 